Article

\title{
One Life/Many Lives: An Internal Hindu-Christian Dialogue
}

\author{
Jeffery D. Long \\ Religious Studies Faculty, Elizabethtown College, One Alpha Drive Elizabethtown, PA 17022-2298, USA; \\ longjd@etown.edu
}

Received: 25 December 2017; Accepted: 27 March 2018; Published: 31 March 2018

\begin{abstract}
This essay consists of philosophical and comparative theological reflections on the topic of rebirth, or reincarnation. Informed by the work of William James, John Hick, and Francis X. Clooney, the essay first establishes the author's stance that reincarnation is a plausible option for belief, at least as attractive as its two main rivals. These rival options are the belief in an everlasting life in either heaven or hell, characteristic of religions such as Christianity and Islam, and the materialist or physicalist belief that there is no afterlife, except in a highly attenuated sense. The essay then moves into a dialogical, comparative theological mode. It raises the question of whether traditional Christian rejection of rebirth, even if it is not something to which the author ultimately assents, might nevertheless carry with it an important insight that is worthy of serious consideration by those who accept the idea of rebirth. This is seen as an instance of the deep learning across religious borders' that is the main goal of comparative theology, as defined by Clooney.
\end{abstract}

Keywords: rebirth; reincarnation; Christianity; Hinduism; comparative theology; Roman Catholicism; Vedānta; theology; eschatology; afterlife; purgatory; past life memory; past lives; consciousness; Bhagavad Gìtā

\section{Introduction}

This essay consists of philosophical and comparative theological reflections on the topic of rebirth, or reincarnation. Informed by the work of William James, John Hick, and Francis X. Clooney, the essay first establishes the author's stance that reincarnation is a plausible option for belief, at least as attractive as its two main rivals. These rival options are the belief in an everlasting life in either heaven or hell, characteristic of religions such as Christianity and Islam, and the materialist or physicalist belief that there is no afterlife, except in a highly attenuated sense. The essay then moves into a dialogical, comparative theological mode. It raises the question of whether traditional Christian rejection of rebirth, even if it is not something to which the author ultimately assents, might nevertheless carry with it an important insight that is worthy of serious consideration by those who accept the idea of rebirth. This is seen as an instance of the 'deep learning across religious borders' that is the main goal of comparative theology, as defined by Clooney.

\section{Philosophical Methodology: Drawing from William James and John Hick}

In his groundbreaking work, now a classic in the field of the study of religion, The Varieties of Religious Experience, William James says of philosophy that it:

fails to prove its pretension to be 'objectively' convincing... It does not banish differences; it founds schools and sects just as feeling does. I believe, in fact, that the logical reason of man operates in this field of divinity exactly as it has always operated in love, or in patriotism, or in politics, or in any other of the wider affairs of life, in which our passions or our mystical 
intuitions fix our beliefs beforehand. It finds arguments for our convictions, for indeed it has to find them. It amplifies and defines our faith, and dignifies it and lends it words and plausibility. (James 1982, p. 436)

Few topics are as emotionally sensitive or as susceptible to the influence of wishful thinking as human beliefs about what, if anything, happens to our consciousness after the death of the physical body. Our beliefs on this topic are tied to our intense desire not to be forever parted from our loved ones, by our sense of justice (that good should be rewarded and evil punished, especially if this did not occur during the life of the deceased person), and by our views about the limits and scope of the natural sciences. In addition, wishful thinking on this topic, as philosopher David Ray Griffin argues, can be 'positive' and 'negative' (Griffin 1997, pp. 26-33). In other words, it is not only that people believe in some kind of afterlife out of the hope of a possible reunion with their departed loved ones, or out of dread of their own mortality. It is also the case that there are people who disbelieve on a similarly non-rational basis: who are deeply invested in the idea that there is no afterlife.

Given the sensitivity of this topic, the depth of the feelings that it evokes, and the ambiguity of the available empirical data, such as it is, it is not at all likely that these questions-'What happens to our consciousness on the death of the body? What happens to us after we die?' - will be resolved in a conclusive and universally compelling way in the near future.

What is possible, as James asserts, is to develop "arguments for our convictions," to "amplify and define our faith," whatever it may be, "and dignify it and lend it words and plausibility." In short, whatever one's beliefs about an afterlife (or the absence thereof-or, in the case of this essay, about afterlives), even if it is not possible to develop an argument that will be universally persuasive, it is possible to show that one's choice to believe in a particular model of the afterlife can be given a rational defense. One of the chief aims of this essay is to begin the process of outlining just such a rational defense.

This essay thus takes a Jamesian perspective on the reflections it presents. It aims not to convince any and all readers that rebirth or reincarnation is a real phenomenon, but rather that belief in the reality of rebirth is at least as plausible as the other available answers to the question, 'What happens after we die?' Believers in rebirth are thus not, simply by virtue of this belief, irrational 'kooks,' but rational agents responding intelligently to the universal human phenomena of death and loss.

In another famous essay titled The Will to Believe, James argues that in those areas of life in which scientific answers are not forthcoming, we are justified in believing as our inclinations take us:

Science can tell us what exists; but to compare the worths, both of what exists and of what does not exist, we must consult not science, but what Pascal calls our heart. Science herself consults her heart when she lays it down that the infinite ascertainment of fact and correction of false belief are the supreme goods for man. Challenge the statement, and science can only repeat it oracularly, or else prove it by showing that such ascertainment and correction bring man all sorts of other goods which man's heart in turn declares. (James 2017, p. 23)

Philosopher of religion John Hick points to the chief difficulty of James' position, but then goes on to suggest a solution to it, building further upon James' thought:

The weakness of his position ... is that it would authorize us to believe anything that we have a strong enough propensity to believe providing the evidence concerning it is inconclusive. If we would like some unprovable proposition to be true, then, given that the option is for us a live, momentous and forced one, James' argument would justify us in believing it. But this virtually amounts to a license for wishful thinking. (Hick 1989, p. 227)

Hick's modification of James' position to compensate for this potential weakness is to "substitute compelling religious experience for the mere desire to believe an unproved and undisproved proposition." As Hick elaborates: 
James' basic argument then becomes an argument for our right to trust our own religious experience and to be prompted by it to trust that of the great religious figures. Thus if in the existing situation of theoretic ambiguity a person experiences life religiously, or participates in a community whose life is based upon this mode of experience, he or she is rationally entitled to trust that experience and to proceed to believe and to live on the basis of it. ${ }^{1}$

This attitude of trust is not incompatible with, but indeed invites critical self-reflection, including reflection on the possibility that one's entire worldview may prove to be deluded:

There is, then, on the one hand an 'experience of existing in the presence of God' [by which Hick means any given religious experience of a compelling nature], which may be approved as authentic by the criteria of the individual's tradition. Such experience constitutes a good prima facie ground for religious belief. But on the other hand there is the possibility that this entire realm of experience may be in toto illusory. I suggest that in these circumstances it is wholly reasonable for the religious person to trust his or her own experience and the larger stream of religious experience of which it is a part. Such a person will, if a philosopher, be conscious of the ever-present theoretical possibility that it is delusory; but will, I suggest, rightly feel that it would be irrational to base life upon this theoretic possibility. Why should one forego entry into a larger universe of meaning, which claims and seems to represent the actual structure of reality, simply because there is always the general possibility of delusion ${ }^{2}$

The openness Hick describes to the possibility that one's experiences may be deluded need not be incompatible with a deep religious commitment. Indeed, world religious traditions themselves treat personal religious experience with some measure of skepticism, mindful of the possibility that an individual might be deluded by such experience into rejecting the worldview of the tradition in question. ${ }^{3}$ Traditions even include the criteria to which Hick refers for differentiating authentic experiences from delusory ones. ${ }^{4}$ Affirming an idea on the basis of experience and tradition need not imply an abdication of responsibility to the truth, and to norms of logic and critical thinking accepted regardless of religious affiliation.

This essay thus proposes to treat rebirth seriously as part of a total worldview in which the author and several considerable streams of religious tradition find a plausible account of their experiences. It is an account that is not incompatible with science, and that carries with it a strong capacity for allowing its adherents "entry into a larger universe of meaning" and an ability to transform the lives of these adherents in positive ways.

\section{Approaching Reincarnation from a Comparative Theological Perspective}

After outlining its argument for the plausibility of reincarnation, this essay will turn from philosophy to comparative theology, as defined by Francis X. Clooney: that is, "deep learning across religious borders" (Clooney 2010). As Clooney defines it, comparative theology is a mode of discourse pursued by committed adherents to a religious tradition who engage in a close study of another tradition. This study is pursued not with the aim either of converting or being converted, but for the sake of learning from the other and bringing back insight to the comparative theologian's own religious tradition.

Comparative theology-comparative and theological [from] beginning to end-marks acts of faith seeking understanding which are rooted in a particular faith tradition but which,

Ibid, p. 228.

Ibid.

A famous example of a mystic who questioned the veridicality of her own experiences is St. Theresa of Avila, from the Roman Catholic tradition of Christianity. See (Theresa of Avila 1979).

4 This topic and that of the epistemic status of religious experience in general are explored in depth in (Alston 1991). Alston argues, like Hick, for the rational validity of using religious experience as a basis for knowledge claims. 
from that foundation, venture into learning from one or more other faith traditions. This learning is sought for the sake of fresh theological insights that are indebted to the newly encountered tradition/s as well as the home tradition ... Comparative theology thus combines tradition-rooted theological concerns with actual study of another tradition. It is not an exercise in the study of religion or religions for the sake of clarifying the phenomenon. It reduces neither to a theology about religions, nor to the practice of dialogue [although, as Clooney notes elsewhere, a 'theology about religions' (or theology of religions) and the practice of interreligious dialogue can and do inform the practice of comparative theology]. ${ }^{5}$

\section{A Catholic who became Hindu Looks Back at Christianity}

The particular comparative theological project pursued in this essay has a somewhat idiosyncratic character. I am not a Christian studying Hinduism, nor am I a Hindu by birth who is studying Christianity. The theological dialogue presented here has the character of an internal dialogue pursued by a person who started out as a Roman Catholic Christian, but who later became an adherent of a Hindu tradition (specifically, the Vedānta tradition of Sri Ramakrishna and Swami Vivekananda), and who is now raising the question whether Christianity might have something valuable to offer to Hindus on the subject of rebirth.

One of the major reasons for my transition from Christianity to Hinduism was my strong preference for the idea of rebirth over traditional Christian ideas about the afterlife. As the essay will show, this essential preference has not changed. I still hold that rebirth is the most plausible of the available afterlife options, and as already stated, I hope to make, or at least outline, a case for its rational defensibility.

Another Hindu ideal that is central to my worldview, though, is dharma samanvaya, which means 'the harmony of religions,' or religious pluralism. This is the view that there is truth in all traditions. The challenge I have posed for myself in this essay is to address the question: Even if I do not agree with the Christian denial of rebirth, it being a central reason for my break with Christianity, is there an important truth that this denial captures?

Bradley Malkovsky has summarized this denial well in the abstract for his paper for this special issue of Religions:

Mainstream Christianity has always rejected reincarnation teaching in all its varieties ... as being incompatible with the biblical understanding of the uniqueness, dignity, and value of the human person, a teaching that is ultimately rooted in the radical understanding of divine mercy and love toward every human being proclaimed by Jesus himself. (Malkovsky 2017)

My response is that, although there are strong reasons for finding the doctrine of rebirth persuasive, Christianity also makes a valid point in its emphasis on the "uniqueness, dignity, and value" of each lifetime. A dialogue with Christians on this topic is an occasion for highlighting dimensions of the idea of rebirth that may otherwise receive little attention in a conversation focused only on the contrasts between Hindu and Christian visions of the afterlife. The aim of this dialogical portion of my essay is not to show that one side or the other is right and that the other is wrong. My view on that issue should be clear, if for no other reason than my chosen religious affiliation, as well as the argument of philosophical section. The aim of this dialogue is a deepened understanding of the idea of rebirth by way of interfaith engagement. And, of course, faith seeking understanding is the definition of theology, dating to the work of St. Anselm: fides quaerens intellectum. ${ }^{6}$

5 Ibid, p. 8.

6 See (Ward 1973). 
This essay will also include reflections on a series of interactions I have had with a student whom I shall call Matthew (not his real name) who is inclined to believe he may be the reincarnation of a very well-known historical figure whose life and character are quite familiar to me. I am not entirely persuaded that Matthew is the reincarnation of this figure-nor, for that matter, is Matthew. We are both simply open to the possibility, based on a set of experiences that Matthew has had and which he has discussed with me in depth. Frankly, I have hesitated to include this material. Given privacy considerations, I offer the barest sketch of these interactions here. I have found, though, that entertaining the idea, as a thought experiment, that Matthew might indeed be the reincarnation of this particular famous person, has yielded insight into the topic of this special issue of Religions that I would like to include in it. This portion of the essay could perhaps be seen as an addendum, only to be read by those with an intense interest in this topic and my approach to it.

\section{Religious Stance: Belief in the Reality of Rebirth in the Modern Vedānta Tradition}

As a Hindu theologian in the tradition of Sri Ramakrishna and Swami Vivekananda, I am operating from a perspective which takes rebirth to be a real phenomenon. Both Sri Ramakrishna and Swami Vivekananda, as well as other teachers in the Vedanta tradition they established, make reference to rebirth in their teachings, and the ideal is presupposed throughout the premodern Vedanta tradition as well. The two main primary sources on the life and teachings of Ramakrishna-two Bengali texts called Śrī Śrì Rāmakrṣna Kathāmṛta and Śrī Śrī Rāmakrṣna Lìlāprasanga-contain numerous references to rebirth, as do the Complete Works of Swami Vivekananda.

The fact that I am located in a tradition that affirms the reality of rebirth is not, of course, sufficient reason for anyone outside of that tradition to see the reality of rebirth as anything other than an assertion, or a statement of faith. My intent in this section is simply to give a sense of how the idea of reincarnation is viewed in the tradition in which I am located. There are many different models of rebirth, in both India and the West, as well as in other cultures, some of which are explored in other essays in this volume. This section should give some idea of what I mean by 'rebirth' and 'reincarnation' when using these terms and arguing for the plausibility of belief in this phenomenon.

In the Kathāmrta, written by Mahendranath Gupta, a householder devotee of Sri Ramakrishna, and translated into English as The Gospel of Sri Ramakrishna by Swami Nikhilananda, Ramakrishna makes a casual reference to people who are very dear to him. "I feel as if they had been my friends in a former incarnation." At this, someone asks, "Sir, do you believe in the reincarnation of the soul?" Sri Ramakrishna replies, "Yes, they say there is something like that. How can we understand the ways of God through our small intellects? Many [authoritative] people have spoken about reincarnation; therefore I cannot disbelieve it" (Nikhilananda 1942, p. 153). He then cites an example from the Mahäbhārata.

This is basically an argument on the basis of religious tradition. The idea of rebirth is ancient and widespread across the entire variety of Hindu traditions, and in other Indic traditions such as Jainism, Buddhism, and Sikhism. With this statement, Ramakrishna is simply locating himself in this larger cultural and religious current of thought.

Later, in the same text, Sri Ramakrishna is asked, "Sir, what is the nature of the life after death?" Ramakrishna replies, "As long as a man remains ignorant, that is to say, as long as he has not realized God, so long will he be born. But after attaining Knowledge he will not have to come back to this earth or to any other plane of existence." 7 This is a reference to the classical Vedāntic view that one is reborn, either on the earth or in another plane of existence, until one attains the realization of the identity of the self, or àtman, and brahman, the infinite being, consciousness, and bliss that forms the ground, source, and ultimate destination of all entities. With this realization comes freedom-mokṣa or $m u k t i-i n$ the form of release from samsāara, the cycle of birth, death, and rebirth. If, in his earlier 
statement, Ramakrishna is locating himself in the Hindu tradition—or family of traditions-broadly conceived, with this statement he locates himself specifically within the Advaita, or nondual, Vedānta tradition, which traces itself to the Upanișads.

Finally, Ramakrishna presents his distinctive approach to this topic, which marks the modern Vedānta tradition that takes him as its chief inspiration. Specifically, he gives an answer which emphasizes direct experience over the pronouncements of traditions and texts. He states that, rather than speculate intellectually about such topics, it is far better to seek the direct experience of God-realization. A devotee asks Ramakrishna, "Sir, is there such a thing as reincarnation? Shall we be born again?" Ramakrishna replies, "Ask God about it. Pray to Him sincerely. He will tell you everything ... It is not right to try to know these things at the beginning. First of all realize God; then He Himself will let you know whatever you desire." ${ }^{8}$ This statement of Ramakrishna's is evocative of Matthew 6:33: "But seek first the kingdom of God and his righteousness and all these other things shall be given to you as well."

In the other main source on the life of Ramakrishna, the Lilapprasanga, written by one of Ramakrishna's original monastic devotees, Swami Saradananda and translated into English by Swami Chetanananda as Sri Ramakrishna and His Divine Play, we find, first, a reference to the Yoga Sütras of Patañjali, "Through the perception of past impressions comes the knowledge of past lives." ${ }^{\prime \prime}$ This is elaborated as follows:

The scriptures say that aspirants attain the memory of past lives before they become fully established in pure consciousness by way of the nondual attitude. Or, at the culmination of that attitude, the aspirant's memory reaches such an advanced state that the aspirant remembers how, where, and how many times he was born, and also everything he did in every previous incarnation, whether good or bad. Consequently, the aspirant fully realizes the impermanence of all worldly objects and the futility of being born again and again to chase sense objects for enjoyment. An intense detachment then arises in the aspirant's mind, which makes that person free from all desires forever. (Chetanananda 2003, pp. 316-17)

The same text also includes an account of a prediction by Sri Ramakrishna that he would, himself, not attain liberation immediately, but that his mission to aid in the liberation of others would require him to be reborn:

... [T] he Master realized that he would not attain liberation like other beings [jīvas]. It does not take long to understand this through ordinary reasoning: He who is always inseparable from God and is indeed a part of God, who is by nature pure, awakened, and free at all times, and who has no deficiency or any limitation-how can the question of liberation arise for such a person? As long as God continues to redeem all human beings, He will have to accomplish this by becoming incarnate in every age. So how could the Master have liberation? As the Master used to say, "An officer of the landlord must run to any part of the estate where there is trouble." He not only knew this about himself through his yogic insight, but he also told us many times, pointing to the northwest, that the next time he would reincarnate there. Some of us said that the Master even told them the time of his advent, stating, "I shall be born in that direction after two hundred years. Then many will be liberated, and those who fail at that time will have to wait a long time for liberation." 10

In addition to these firsthand accounts by devotees of Sri Ramakrishna, which give an idea of his views on rebirth, there are also references to this concept in the Complete Works of his best known disciple, Swami Vivekananda.

\footnotetext{
$8 \quad$ Yoga Sūtras 3:18.

9 Yoga Sūtras 3:18.

10 Ibid, p. 360.
} 
Vivekananda presents a moral argument for reincarnation, connecting this idea with theodicy-the problem of evil. Rather than laying the responsibility for all our suffering at the feet of God, reincarnation, according to Vivekananda, makes us responsible for our own suffering. This is not seen as a message of blame or of guilt, but of hope; for what we can do, we can undo, given the potentially infinite second chances provided by the concept of rebirth:

This idea of reincarnation runs parallel with the other doctrine of the eternity of the human soul. Nothing which ends at one point can be without a beginning and nothing that begins at one point can be without an end. We cannot believe in such a monstrous impossibility as the beginning of the human soul. The doctrine of reincarnation asserts the freedom of the soul. Suppose there was an absolute beginning. Then the whole burden of this impurity in man falls upon God. The all-merciful Father responsible for the sins of the world! If sin comes in this way, why should one suffer more than another? Why such partiality, if it comes from an all-merciful God? Why are millions trampled underfoot? Why do people starve who never did anything to cause it? Who is responsible? If they had no hand in it, surely, God would be responsible. Therefore the better explanation is that one is responsible for the miseries one suffers. If I set the wheel in motion, I am responsible for the result. And if I can bring misery, I can also stop it. It necessarily follows that we are free. There is no such thing as fate. There is nothing to compel us. What we have done, that we can undo. (Vivekananda 1979, p. 329)

Vivekananda also makes an argument for reincarnation on the basis of memory: that there are certain tendencies (samskāras) that can be found, particularly in children, which cannot easily be accounted for by training, or 'nurture.' The only explanations for these tendencies are genetics, or 'nature,' or, for those who believe in a soul, reincarnation:

We gain all our knowledge through experience; that is the only way. What we call experiences are on the plane of consciousness. For illustration: A man plays a tune on a piano, he places each finger on each key consciously. He repeats this process till the movement of the fingers becomes a habit. He then plays a tune without have to pay special attention to each particular key. Similarly, we find in regard to ourselves that our tendencies are the result of past conscious actions. A child is born with certain tendencies. Whence do they come? No child is born with a tabula rasa—with a clean, blank page-of a mind. The page has been written on previously. The old Greek and Egyptian philosophers taught that no child came with a vacant mind. Each child comes with a hundred tendencies generated by past conscious actions. It did not acquire these in this life, and we are bound to admit that it must have had them in past lives ... Now if heredity alone explains this, there is no necessity of believing in the soul at all, because [the] body explains everything... So far the way is clear for those who believe in an individual soul. We see that to come to a reasonable conclusion we must admit that we have had past lives." 11

It is interesting to note that Vivekananda's stance in this regard is not unlike that which would later be taken by John Hick on religious experience, as discussed earlier, inasmuch as Vivekananda allows for the possibility that his belief in rebirth may turn out to be delusory. A materialist explanation for the tendencies he describes is available, in the form of heredity. However, the idea of reincarnation is available—and, according to Swami Vivekananda, inescapable- "for those who believe in an individual soul."

What is this 'individual soul,' according to the Vedānta tradition? What is it that is reborn? Punarjanma, or rebirth, in all the various systems of Vedānta, refers to the idea that each of us is, at our

11 Ibid, pp. 329-30. 
most basic level, a being of pure consciousness, or jiv $v a$, that has manifested on the material plane in, or as, a material form which is conventionally known as a body (a deha or śarìra, in Sanskrit). This jīva, as Vivekananda explains, has no beginning and no end in time. In the words of the Bhagavad Gittā:

There never was a time when I did not exist, nor you ... And there never will be a time when we do not exist. Just as the embodied one [dehin] experiences childhood, and youth, and old age, in this body, in the same way he enters other bodies. A wise person is not disturbed by this ... Just as one discards worn-out clothes and gets others that are new, so the embodied one discards worn-out bodies and enters others that are new. ${ }^{12}$

In the Advaita, or nondualist, system of Vedānta, even the jīva does not define our ultimate identity. All of us are ultimately, according to Advaita, one with the singular ātman, the divine Self at the heart of all existence. From an Advaita perspective, belief in rebirth plays a soteriological role as one step in a longer process of destabilizing our conventional sense of identification with the physical body, and finally, our identification with anything other than consciousness itself. ${ }^{13}$ The àtman is essentially pure consciousness; for Brahman is consciousness—prajñannam brahma ${ }^{14}$ —and the àtman is Brahman—ayam ātmā brahma. ${ }^{15}$ We therefore move from identifying with our physical body and with the personality we have developed in this lifetime to identifying with the soul, or jīva, which has assumed myriad forms throughout cosmic time, and then move from identifying even with the soul to identifying with the pure and infinite consciousness that manifests in and as all souls.

How did I, personally, come to hold this religious stance? To again cite Hick, what 'compelling religious experience' led me to adopt it? As I have recounted elsewhere, I first read the just-cited words of the Bhagavad Gitta at the age of fourteen, in the aftermath of my father's very public suicide, which was the culmination of his long struggle with physical disability. ${ }^{16}$ Coming across the Gita $\bar{a}$, seemingly by chance, in the most unlikely of places (a flea market in the parking lot of the Methodist Church of my small Missouri hometown), was an event that changed my life, resolving a host of issues that had arisen in my mind while coping with the tragedies and shocks that had befallen my family. I felt, in that moment, that I had been given a divine revelation.

From a perspective of scientific rigor, the fact that I find the doctrine of rebirth to be deeply reassuring-and moreover, that I ascribe my adoption of this doctrine to a personal divine revelation-probably disqualifies any further pronouncements from me on this topic from being taken seriously. However, it is, of course, also true that the fact that an idea is deeply reassuring does not mean it is necessarily false. The arguments for (and against) this idea need to be taken on their own merits.

Again, though, my aim here is not to prove conclusively that rebirth, as understood in the Vedānta tradition, is a real phenomenon. It is to prove that belief in this phenomenon is not unreasonable, particularly in contrast with the other possible answers to the question, 'What happens after we die?' So what is the case for the plausibility of reincarnation?

\section{Why Believe in Rebirth? Outline of an Argument for the Plausibility of Reincarnation}

Briefly, there are three basic arguments for rebirth. I call the first argument moral-theological. The second one is empirical. The third I call pragmatic-soteriological. None of these arguments is, by itself, completely airtight. Each of them can be rejected, or at least questioned, by reasonable persons. Cumulatively, however, they demonstrate that the idea of rebirth is not beyond the pale of plausibility for other, equally reasonable persons.

\footnotetext{
Bhagavad Gītā, 2:12-13, 22. (Thompson 2008), with minor modifications on my part.

For more detailed discussion of the deconstructive soteriological strategies of Advaita Vedānta, see (Davis 2010).

Aitareya Upanișad 3:1:3.

Mandukya Upanișad 1:2

See (Long 2012, 2015).
} 
The arguments for rebirth function in a way that is akin to that in which arguments for the existence of God function, according to philosopher of religion Richard Swinburne. Swinburne sees the traditional arguments for the existence of God-such as the ontological argument, the cosmological argument, the teleological argument, and so on-not as airtight on an individual basis, but taken together, to be cumulatively persuasive. Using an image of a set of leaky water buckets, he argues that each bucket, individually, may be unable to hold water, but that they can be stacked together in such a way as to render them capable of serving this purpose. As Swinburne explains, " ... arguments that are not deductively valid are often inductively strong; and, if you put three weak arguments together, you may often get a strong one, perhaps even a deductively valid one" (Swinburne 2004, p. 13).

The moral-theological argument for rebirth operates on the assumption, shared by many religions, that there is a benevolent and ultimately just cosmic order which defines the wider context of human existence. This order-or dharma - can operate with or without the presence of a divine guarantor of that order, as the existence of both theistic and non-theistic Dharma traditions attests. ${ }^{17}$

From this perspective, given the alternatives normally presented in response to the question of the afterlife, rebirth is seen to fulfill the criteria of benevolence and justice in a more satisfactory way than either the model of an eternal heaven or hell that is upheld in the mainstream Christian and Islamic traditions, or the secular model in which there is no afterlife (except in the very attenuated sense in which persons and the effects of their lives continue on in the memories of others, or through the passing on of their genetic, cultural, or intellectual inheritance). What is the basis for this assertion? What makes reincarnation more consistent with a just and benevolent cosmic order than the heaven-and-hell model or the materialist model?

Put briefly, the problem with heaven and hell is that most people are neither good enough to spend an eternity in heaven nor evil enough to spend an eternity in hell. Even if one allows that a few beings in a given cosmic epoch might, as Dharma traditions affirm, attain perfection, one lifetime is not, as these traditions also affirm, time enough to achieve this ultimate goal. To say that a soul might reach a point of no return, without any ability whatsoever to improve, and thus spend eternity in hell, is a highly arbitrary and horrifying conclusion. Indeed, when combined with traditional theism, it suggests that God, knowing some beings will end up suffering forever, nevertheless goes ahead and creates them, thus becoming responsible for their torment. This is arguably a sadistic and psychopathic vision of divinity: the very one which we have seen strongly rejected by Swami Vivekananda as 'monstrous.' In addition, while ideals of divine mercy and unmerited grace certainly have a major role to play in many religious traditions, including many Hindu traditions, the idea that one is received into eternal bliss after one lifetime, even one riddled with imperfections, offends one's sense of justice. One is sympathetic, here, to the perspective of the brother of the prodigal son, who sees his brother welcomed home with open arms and a celebration after wasting his father's wealth, while he himself, who has been faithfully obedient, receives no such reward. Neither heaven nor hell, from this point of view, seems an appropriate or proportional outcome of the typical human life, with its mix of perfection and imperfection. Benevolence and justice together seem best fulfilled by an afterlife that contains a mix of happiness and sorrow, but also ongoing opportunities to improve oneself.

The Catholic perspective, with which I was raised, mitigates the problems of the heaven-and-hell model with the concept of purgatory, in which not-yet-perfected souls who are nevertheless in a state of grace, and so ultimately destined for salvation, continue to work out their imperfections in an intermediate state, between the time of the death of the physical body and the attainment of the beatific vision in its fullness.

As Bradley Malkovsky points out, though, in his contribution to this volume, this working out of imperfections in purgatory does not, as traditionally conceived, involve the cooperation of the free will

17 Buddhism and Jainism are thus non-theistic, whereas Sikhism and most Hindu traditions are theistic. See (Howard 2017). 
of the individual soul. Though he ultimately rejects the idea of reincarnation, Malkovsky concedes that, on this point, the doctrine of reincarnation has an advantage over the traditional concept of purgatory:

The doctrine of purgatory, it is true, also includes the notion of post-mortem transformation, Rahner points out, but not on the basis of a continued exercise of freedom. It is perhaps surprising, then, that Catholic teaching rejects the possibility that free will continues beyond earthly existence into the afterlife. This is the advantage of reincarnation doctrine; it offers further opportunity for self-determining freedom. ${ }^{18}$

There are other issues with purgatory as well. Apart from the fact that it retains the possibility of eternal damnation for some-namely, those who did not die in a state of grace-another problem with the purgatory solution is that it raises the question of the point of one's physical incarnation on earth. If the soul still has work, perhaps a great deal more work, to do at the time of the death of the body, and if this work is to be done in purgatory, why did the soul not simply begin its journey in purgatory? What was the purpose of being born in the physical world at all? The idea of rebirth, in these terms, in effect amounts to the claim, that we are already in purgatory, doing the work—the karma —-that we need to do for the sake of our eventual perfection. One's current life, in effect, is the purgatory of the one which immediately preceded this one.

Regarding the other alternative- that there is no rebirth because there is no soul or afterlife in any traditional sense-I am persuaded by John Hick's argument that this view is "bad news for the many" (Hick 2004, pp. 19-24). This is of course not an airtight argument. The fact that a worldview is incredibly bleak and suggests that the vast majority of human beings have lived lives that are, to quote Thomas Hobbes, "nasty, brutish, and short," with no ultimate redemption or sense that these persons have anything better to look forward to after death, does not mean it is necessarily false. It may simply be the case that we live in a horribly unjust and monstrous universe, not unlike that of the heaven and hell model, but without the comfort of a heaven for the chosen few. Such a materialist view does, however, raise troubling moral questions, such as the question "Why be moral at all?" These questions are not incapable of being answered, and thinkers such as 'new atheist' Sam Harris have been striving valiantly to answer them. However, as Hick has said:

Why should one forego entry into a larger universe of meaning, which claims and seems to represent the actual structure of reality, simply because there is always the general possibility of delusion? ${ }^{19}$

In short, although the materialist rejects reincarnation because it has not been scientifically proven, so long as it has also not been scientifically disproven, it satisfies both Hick's and James' criteria as a valid option for belief.

As the next argument suggests, however, it may not actually be necessary, in light of recent scientific developments, even to contemplate casting aside the possibility of a spiritual realm in order to remain faithful to a scientific vision of reality. It may indeed be that, in the near future, the survival of consciousness beyond the death of the body will become a topic of mainstream scientific investigation.

The empirical argument for rebirth is based on the research into past life memory that was famously pursued by the late Ian Stevenson and that continues to be pursued by his successor, Jim Tucker, in the department of psychiatry at the University of Virginia.

To the possible objection that past life memory studies in the West are not relevant to Indic models of reincarnation, such as the Vedāntic model, and that past life memory is a relatively recent phenomenon, we have already seen mention made in an ancient Indic text—-the Yoga Sütra — to past life memory. The idea of past life memory, indeed, undergirds an entire genre of early Buddhist 
literature: the Jâtaka tales, which claim to present the past life memories of the Buddha. In addition, in the Bhagavad Gittā, Krishna makes mention to Arjuna of his ability to recall past births:

I taught this eternal yoga tradition to Vivasvat, the god of the sun. Vivasvat taught it to Manu, the Father of mankind. Manu himself taught it to Ikṣvāku, the first king.

The royal seers knew this tradition, which was handed down from one to the other, but after a long passage of time, Arjuna, it became lost.

This ancient yoga tradition is what I teach to you today, for you are my devotee and my friend, and this is the deepest of mysteries.

Arjuna spoke:

Vivasvat's birth occurred a long time ago. You were born much later. How should I understand what you mean when you say that you taught this teaching in the beginning?

The Blessed One spoke:

I have passed through many births, and so have you, Arjuna. But I can recall them all whereas you, Arjuna, cannot. ${ }^{20}$

Stevenson's research on children who claimed to remember past lives, some of the details of which could be verified with further investigation, has been rightly questioned on a number of counts, including by Jonathan Edelmann, another contributor this volume (Edelmann and Bernet 2007). Such alleged memories are typically corrupted through the introduction of the idea of reincarnation and whatever biases in favor of or against the idea that the child or his or her family might have. The collection of these stories does not occur in laboratory conditions.

Tucker, however, as recounted in his recent popular works such as Return to Life: Extraordinary Cases of Children Who Remember Past Lives (Tucker 2015), has tightened the methods of his predecessor, exerting considerable effort to eliminate factors like leading questions, and treating with greater skepticism accounts emerging from cultural environments where the idea of rebirth is strongly affirmed. It is not that these accounts are necessarily false; but for an account to be taken as valid, all bias factors must be rigorously removed. In addition, again, to respond to the objection that cases from Western countries cannot have relevance to the Vedāntic model of rebirth, raising this objection would seem to be akin to arguing that Einstein's formula $\mathrm{E}=\mathrm{mc}^{2}$ applies only to energy and matter in Austria. The Vedāntic model teaches that the jīvas have been reincarnating throughout the multiverse throughout cosmic time. If anything, cases of past life memory from cultures outside of India would seem to lend weight to this model.

If large numbers of Stevenson's and Tucker's cases are invalidated, though, does this not suggest that the attempt to ground belief in reincarnation on the basis of past life memory is doomed to failure?

In the words of William James, who famously studied paranormal phenomena (as recounted by David Ray Griffin in his 1997 study of this topic) (Griffin 1997), "it takes only one white crow to prove that not all crows are black." In other words, even if, out of the thousands of accounts collected by Stevenson and Tucker, only one was to meet criteria of scientific rigor-not being prompted by parents or other relatives, not being derived from books or the Internet, not referring to a famous personage whose life details were well known, and not occurring in the context of a pre-existing belief in reincarnation - this alone would be sufficient to demonstrate, at minimum, that consciousness is not the mechanistically-based phenomenon that materialist ontologies presuppose: that information can transfer from one mind to another through means not yet recognized by the mainstream scientific community in the western world (but for which quantum theory creates an opening). 
Such a case, it seems, exists: the case of Ryan, documented by Tucker in Return to Life, and appearing on the NBC Nightly News on 20 March 2015 (which is how I first became aware of this case). Ryan, a young boy from Oklahoma, is from a conservative evangelical Christian family. Belief in reincarnation is strongly rejected in this religious tradition as a false doctrine, and the broader American culture in which the family lives is strongly skeptical of the concept, with most Americans still rejecting this idea. There is thus, for Ryan or his family, no positive motive or cultural impulse to advance the idea of reincarnation. Indeed, the potential for ridicule and social sanctions such as ostracism is very real in this case, thus lending some weight to its validity from the outset.

Around the age of four, "Ryan began talking about going home to Hollywood. He would cry and plead for Cyndi [his mother] to take him home so he could see his other family" (Tucker 2013, p. 88). These experiences were sufficiently disruptive that Ryan's family took him to the University of Virginia for a consultation with Tucker-who is, again, a well-reputed child psychiatrist. Collecting Ryan's detailed accounts of his alleged past life, and correlating them with carefully researched information, Ryan's parents and Tucker concluded that the life Ryan was describing was that of Marty Martyn, an agent from the golden age of Hollywood. This was not a person of any particular fame, and a person with no connection to Ryan or his family.

Importantly, the details Ryan articulated were not readily available, such as on the Internet, and no one in Ryan's family, nor Tucker, had any knowledge of Martyn prior to engaging in this research.

In the most striking portion of the entire story, Ryan at one point said, with some frustration, that he did not understand why God would allow someone to live for sixty-one years and then make them come back as a baby. All of Ryan's information about Martyn's life at this point had proven accurate, but on this one point of fact, his account was at odds with Martyn's official death certificate, which stated that Martyn had died at the age of fifty-nine. Given the rigor of his methodology, Tucker was prepared to see this one discrepancy as a sufficient basis for rejecting Ryan's story as a proof of the phenomenon of rebirth. Further research, however, proved that Martyn had in fact died at the age of sixty-one, and that the birth certificate was incorrect. Ryan therefore not only had detailed information about the life of a man no one in his family had ever met and about whom they had no prior knowledge, but his information actually led to a correction of the public record of the death of that same man.

Is Ryan's story scientific proof of rebirth? Not necessarily. The phenomenon described here is susceptible to a variety of interpretations, including a form of telepathic contact between the deceased Marty Martyn and the living Ryan.

It does, however, raise serious questions about the materialist paradigm used by many to explain phenomena such as consciousness; for even if Ryan's declarations are not repeatable or testable under laboratory conditions, they do leave us with the fact that a young child has been walking around, as far as can be discerned, with detailed memories from the life of a deceased person whom he never met and to whom neither he nor his family had access, in his mind. Even if, under the most rigorous definition of science, this information does not count as proof of rebirth, it certainly renders problematic the standard materialist idea that consciousness is nothing but an effect of neurochemistry, incapable of surviving the death of the brain, and opens up the possibility of the reality of rebirth. As Tucker argues, the development of quantum physics raises similar questions about the viability of materialism, which Tucker sees as having been essentially refuted:

Findings in physics over the last hundred years-particularly in quantum physics or quantum mechanics, the study of the universe's smallest particles-have shown that the physical universe is much more complicated than it appears. They strengthen the view that there is a consciousness that exists separate from the material world. I now believe that the physical grows out of the mental, meaning that the physical world is created out of something you can think of as Mind or consciousness or the spiritual. Our cases, and the 
possibility of children remembering past lives, then fit in nicely with a new understanding of existence. ${ }^{21}$

The 'new understanding of existence' that Tucker describes is, of course, 'new' only in the sense that its possibility being undergirded by the natural sciences is a recent development. This understanding of existence, though, is of course ancient in India, Vedānta being one example of a tradition that has affirmed it for millennia. Brahman is consciousness-prajñ̄nam brahma. In addition, all this-the cosmos-is, indeed, Brahman: sarvam khalvidam brahma. ${ }^{22}$

Finally, the third argument for rebirth is the pragmatic-soteriological one, based on the effects that believing in rebirth can conceivably have upon one's life, at least in the context of a deconstructive spiritual practice such as that of Advaita Vedānta: particularly one's relationship to others and to one's own experiences. These are effects to which I can attest, as my belief in rebirth has solidified from the time I began to entertain the concept, in my early adolescence, to the present. The concept of rebirth expands one's sense of self in way that paradoxically leads to a humbling realization of one's profound connections with all beings. The Buddha famously exhorted his followers to be mindful that, given the vastness of cosmic time and the rebirth process that occurs within it, every person that one meets has likely been one's beloved, one's mother, one's father, one's sister, one's brother, or one's dear friend at some point or other. An important Buddhist spiritual exercise is based on this insight. This exercise involves the recollection that all beings have at some point been one's mother:

Why are all beings my relatives? As there is no beginning to the life-cycle, there has also been no beginning to my rebirths. In passing through these countless lives, there is no form of life which I have not adopted countless times, and there is no country or realm in which I have not been born. Of all beings, there is not one who has not been my mother innumerable times. Each has been my mother in human form countless times, and will become my mother many times again. (Thurman 1995, p. 137)

This realization, rooted in an assumption of the truth of rebirth, militates against prejudice, allowing one to see beyond such differences as gender, ethnicity, religion, nationality—or even species, if one is mindful that the soul is not specifically human, but is pure consciousness, which could well reside and has certainly resided in many forms of life throughout the cosmos. Belief in rebirth, in short, has soteriological benefits, at least within the framework of the Dharma traditions. There is not time or space to argue this in depth here; but I would say that believing in rebirth has made me a better person than I might otherwise be.

These three arguments do not, again, constitute an irrefutable or indubitable case for rebirth. They do, though, collectively suggest that rebirth is neither an unreasonable nor wholly unattractive option, and that assent to this doctrine is intellectually defensible.

\section{Giving a Fair Hearing to Christian Reservations about Rebirth}

Turning, now to comparative theology, and a dialogue between Hinduism and the Christian tradition, let us revisit Bradley Malkovsky's summary of the reasoning behind the mainstream Christian rejection of the idea of reincarnation:

Mainstream Christianity has always rejected reincarnation teaching in all its varieties ... as being incompatible with the biblical understanding of the uniqueness, dignity, and value of the human person, a teaching that is ultimately rooted in the radical understanding of divine mercy and love toward every human being proclaimed by Jesus himself.

21 Ibid, pp. 165-66.

22 Chāndogya Upaniṣad 3:14:1. 
Finding the arguments for rebirth to be persuasive, and the model of the universe presupposed in a worldview in which rebirth is real to resonate with my own intuitions, as well as for a number of other reasons that go beyond the purview of this paper, I was drawn, from a young age, to embrace a Hindu spiritual path. I see the Christian tradition of my upbringing as a repository of much profound wisdom, and I will always be grateful for the spiritual formation I received in this tradition. Its model of the afterlife, however, is one that I ultimately found unsatisfying in contrast with the idea of karma and rebirth.

Another idea that drew me to a Hindu path, however, was religious pluralism - the idea that there is profound truth to be found in all paths, and that each path is a way to the highest realization. Yato mat, tato path, in the words of Sri Ramakrishna: Each tradition is a path to the ultimate reality. I would argue, as a Hindu, that even the rejection of the doctrine of rebirth by Christians carries within it an important truth.

This brings me to my student, Matthew, who believes he may be the reincarnation of a prominent historical personage whose life and character I know very well. If, simply as a thought experiment, I entertain the notion that Matthew really is this person reborn, I find that this yields an important insight into the idea of rebirth —an insight captured in the Christian affirmation of the "uniqueness, dignity, and value" of each person.

Of course, Hindu traditions, and all the Dharma traditions, also teach that each life is precious. A lifetime is an opportunity to advance toward the highest realization. We take rebirth in a particular form because that form and the experiences to which it lends itself are precisely what we need in order to advance at that point in our journey. A famous Hindu teaching is that, "Human birth is precious." 23 While the soul can take any form, and each form carries its own benefit for the soul, a human rebirth carries with it certain special abilities, such as the ability to comprehend the soul's situation, and to engage in sädhana, or intentional spiritual practice. In response to the concern that belief in rebirth might lead to a certain spiritual laziness, to a willingness to put off spiritual practice for a future lifetime, the idea that each human rebirth is precious, that there is no guarantee that one will be able to practice again for a very long time, militates against what might be called spiritual procrastination.

There is even more, though, to the matter than this. The Bhagavad Git $\bar{a}$ 's image of the rebirth process as akin to casting aside old clothes and putting on new ones carries with it a certain bravado in the face of death, which is certainly part of its appeal to those of us who have found reassurance, after the loss of our loved ones, in this idea. Reading the words of Krishna, "Just as one discards worn-out clothes and gets others that are new, so the embodied one discards worn-out bodies and enters others that are new," one wants to add, "Death, where is thy sting? O grave, where is thy victory?" 24 The image is an important one for conveying the immortality of the soul relative to the perishable nature of the material body, to which we ought not, because of this very perishability, to become attached.

Like all analogies, though, this one is imperfect. When I think of Matthew and the person whose reincarnation he might be, the two of them are not the same. Matthew is his own person, with his own aspirations, own experiences, own plans, own friends, own destiny.

At the same time, I can also see the undeniable connections and resonances that may link him to that other. He both is and is not the person whose inner essence he may well share. When I asked him if it was somehow to be proven that he is, indeed, this other person reborn, what difference this would make in his life, he told me that it would help him understand certain feelings that he had, certain likes and dislikes. He also said it would give him confidence. Knowing he had already

23 See (Mangla 2016).

241 Corinthians 15:55, King James Version. 
achieved certain things in the other life would help him believe in himself, and that he could do great things in this life. ${ }^{25}$

The point is that, to be reborn is more than changing clothes (with all due respect to the profound import of that image, and its truth in another context). To be reborn is, in one sense, to carry on as oneself in another form. However, in another sense, from the point of view of that new lifetime, it is to carry within oneself the deep essence of another, who, while in many profound ways is oneself, is in other ways truly other. The destabilizing of the ego that reflection on this process evokes is, of course, part of its whole point, as the pragmatic argument for rebirth suggests. It is part of the transformative soteriological value of this point of view.

This does not mean, though, that the uniqueness, dignity, and value of each person-of each incarnation-ought to be diminished by the concept of rebirth. Rather, the richness and value of the totality of being is increased as the soul takes on a new identity. Each of these identities is a new expression of an ancient reality; yet each also remains an irreducibly distinct contribution to the whole.

Conflicts of Interest: The author declares no conflicts of interest.

\section{References}

Alston, William. 1991. Perceiving God: The Epistemology of Religious Experience. Ithaca: Cornell University Press. Translated by Swami Chetanananda. 2003, Sri Ramakrishna and His Divine Play. St. Louis: Vedanta Society of St. Louis, pp. 316-17.

Clooney, Francis X. 2010. Comparative Theology: Deep Learning across Religious Borders. London: Wiley-Blackwell. Davis, Leesa S. 2010. Advaita Vedānta and Zen Buddhism: Deconstructive Modes of Spiritual Inquiry. London: Continuum. Edelmann, Jonathan, and William Bernet. 2007. Setting Criteria for Ideal Reincarnation Research. Journal of Consciousness Studies 14: 92-101.

Griffin, David Ray. 1997. Parapsychology, Philosophy, and Spirituality: A Postmodern Exploration. Albany: State University of New York Press.

Hick, John. 1989. An Interpretation of Religion. New Haven: Yale University Press, p. 227.

Hick, John. 2004. The Fifth Dimension: An Exploration of the Spiritual Realm. Oxford: Oneworld, pp. 19-24.

Howard, Veena. 2017. Dharma: The Hindu, Jain, Buddhist, and Sikh Traditions of India. London: IB Tauris.

James, William. 1982. The Varieties of Religious Experience. New York: Penguin Books, p. 436.

James, William. 2017. The Will to Believe. Mexico: Midwest Journal Press, p. 23.

Long, Jeffery D. 2012. 'Never Was There a Time ... ' Crossing Over to Hinduism through the Bhagavad Gītā. In My Neighbor's Faith: Stories of Interreligious Encounter, Growth, and Transformation. Edited by Jennifer Howe Peace, Or Rose and Gregory Mobley. Maryknoll: Orbis Books.

Long, Jeffery D. 2015. The Gītā: A Healing Revelation. Sutra Journal. August. Available online: http://www. sutrajournal.com/in-appreciation-of-the-gita-jeffery-long (accessed on 6 March 2018).

Malkovsky, Bradley. 2017. Belief in Reincarnation and Some Unresolved Questions in Catholic Eschatology. Religions 8: 176.

Mangla, Dharam Vir. 2016. Buddhism and Hinduism: A Comparative Study. Delhi: Geeta International Publishers and Distributors.

Translated by Swami Nikhilananda. 1942, The Gospel of Sri Ramakrishna. New York: Ramakrishna-Vivekananda Center, p. 153.

Swinburne, Richard. 2004. The Existence of God, 2nd ed. Oxford: Clarendon Press, p. 13.

Theresa of Avila. 1979. The Interior Castle. Mahwah: Paulist Press.

Thompson, George. 2008. The Bhagavad Gita: A New Translation. New York: North Point Press.

Thurman, Robert A. 1995. Essential Tibetan Buddhism. San Francisco: HarperCollins, p. 137.

25 Just as I am protecting the privacy of my student by giving him a pseudonym, I have also made a choice to respect the privacy of the famous person whose reincarnation he might be. If that person has chosen to reincarnate as my student, I assume that is his business. It is not for me to broadcast it, uninvited, to the world. 
Tucker, Jim B. 2013. Return to Life: Extraordinary Cases of Children Who Remember Past Lives. New York: St. Martin's Griffin, p. 88.

Tucker, Jim. 2015. Return to Life: Extraordinary Cases of Children Who Remember Past Lives. New York: St. Martin's Griffin.

Vivekananda, Swami. 1979. Complete Works. Mayavati: Advaita Ashrama, vol. One, p. 329.

Translated by Benedicta Ward. 1973, The Prayers and Meditations of St. Anselm, with the Proslogion. New York: Penguin Books.

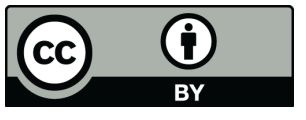

(c) 2018 by the author. Licensee MDPI, Basel, Switzerland. This article is an open access article distributed under the terms and conditions of the Creative Commons Attribution (CC BY) license (http:/ / creativecommons.org/licenses/by/4.0/). 